\title{
The effects of mineralogical and petrographical features of the Lake District rocks (Isparta, Turkey) on the quality of artificial marbles
}

ALI BILGIN - Sırnak University, Department of Mining, Batman, Turkey

GuRKAN YUCETURK - Suleyman Demirel University, Department of Geology, Isparta, Turkey

SoNmEZ ARSLAN - Batman University, Department of Chemistry, Batman, Turkey

NuRSEv BILGIN - Middle East Technical University, Department of Materials Science, Ankara, Turkey SuleYMAN POLAT - Batman University, Department of Geology, Batman, Turkey

Érkezett: 2013. 03. 27. - Received: 27. 03. 2013. - http://dx.doi.org/10.14382/epitoanyag-jsbcm.2013.5

Gurkan YÜCETÜRK

Received his MSc degree from the Süleyman Demirel University, Turkey. Received his PhD degree from the Süleyman Demirel University, Turkey. He is currently project manager at Ekinciler Co, Turkey.

Sonmez ARSLAN

\section{Abstract}

Large quantities of marble blocks are produced from many new marble quarries which were opened around Isparta (Turkey) and its surrounding region. The opened quarries are also affected negatively by weathering as a result of karstification. Therefore, block efficiency of the quarries is low which results in a lot of waste materials that can be used in cultured marble production. The production of artificial marble from marble waste materials around Isparta is the main purpose of the study. The cultured marble is an attractive, healthy and homogenous building material. It has a wide application in the building construction sector. Artificial marble which is composed of mineral dusts and polyesters has high mechanical strength and they are durable to various chemical and high temperature environmental conditions. Based on physico-mechanical properties, cultured marbles are accepted by Turkish Standards (TS). The materials used for the production of qualified cultured marble are directly related to the hardness of the minerals used as filler in the polyester resin. Physico-mechanical properties of cultured marble depend on the physical properties of the filler minerals. The compressive strength of the cultured marble material is controlled by the physical properties of the filler minerals, therefore, the hardness of the cultured marble is determined by the hardness of the filler mineral. The following analyses were carried out: wet unit volume analysis, dry unit volume analysis, compressive strength of the materials, capillary water absorption analysis, analysis of ultrasound velocity (P-wave) and the marble wastes bulk chemical analyses were investigated and the results of the data were evaluated and discussed. In addition, natural and artificial marbles were compared with respect to physico-mechanical properties.

Keywords: artificial marble, polyester resin, marble quarry, compressive strength.

\section{Introduction}

Wastes of rocks similarly to all kinds of construction materials and industrial raw materials used in our daily life may adversely influence the environment. Evaluation of the waste materials and turning into economic value has important issue at present time. Large quantities of marble blocks are produced from many new marble quarries which were opened around IspartaBurdur (Turkey) which has rich marble fields in its surrounding region (Fig. 1). The opened quarries are also negatively affected by weathering as a result of karstification. Therefore block efficiency of the quarries is low and they produce a lot of waste materials [1]. There are many ways to evaluate these produced wastes [2]. Granulated artificial marble dusts in micron size in mills mixing and molding in different ratios with resins have been evaluated as cultured marble artificial construction material [3]. One of the evaluation methods of waste marble is using them in production of cultured marble. The production of artificial marble from natural marble waste materials around Isparta-Burdur area is the main purpose of this research.

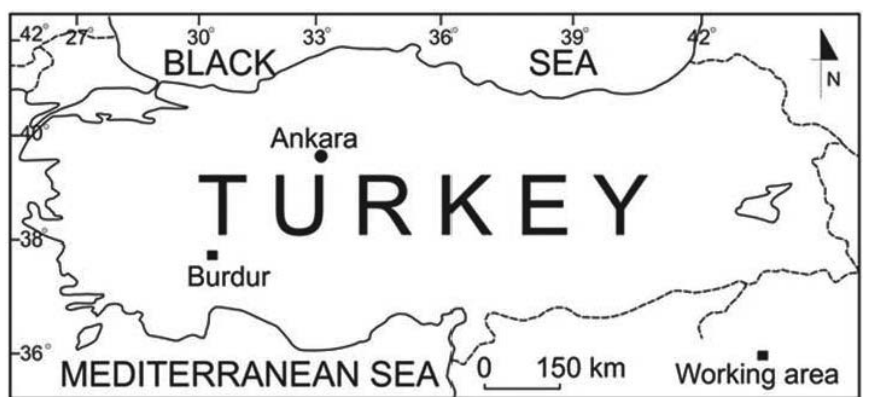

Fig. 1. Location map of the study area.

1. ábra A vizsgálati helyszinek térképvázlata

Marble blocks produced at marble quarries leave huge quantities of marble wastes which results waste marble hills with visual pollution (Fig. 2) [2]. Wollastonite, quartz and other silicate minerals are significant materials used for artifical marble production as well, additional to marble waste. Calcite and dolomite are considered in carbonate group minerals and the effect of the ratios of the resins and additive materials on cultured marble materials is still under discussion [4]. 


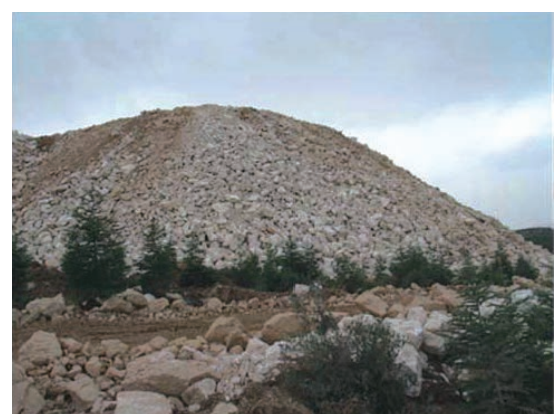

Fig. 2. Waste marble hills in Isparta-Burdur area which cause visual pollution 2. ábra Vizuális szennyezést okozó hulladék márvány dombok az Isparta-Burdur területen

\section{Materials and methods}

\subsection{Samples location}

There are many marble deposits around Isparta and Burdur area. We have collected 12 samples from waste marbles; locations are indicated in Fig. 3.

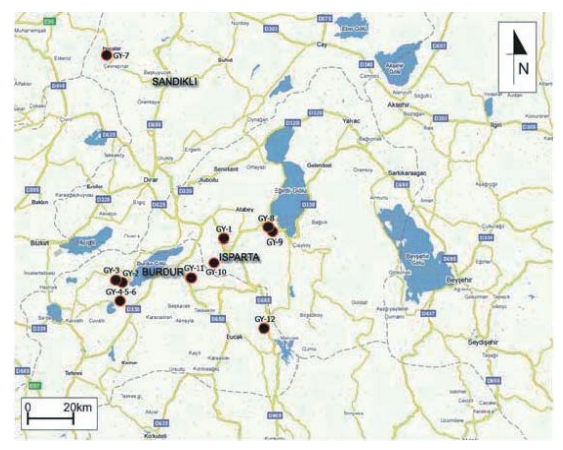

Fig. 3. Waste marble sample locations around Burdur and Isparta. 3. ábra Hulladék márvány mintavételi helyek Burdur és Isparta környékén

\subsection{Used materials for artificial marble production}

Artificial marbles have been produced from calcite, quartz, feldspar and wollastonite that can be found in waste marble dusts mixing with polymer resin materials. Resins are used as binder, calcite, dolomite, quartz and wollastonite minerals are used as aggregate/filler for cultured marbles and waste glass is also used for artificial marble production as additive material [5].

\section{Results and discussions}

\subsection{Texture of artificial marbles}

Polarization microscopy analysis was made first to study the texture of artificial marble raw materials. For the inspection, sections of $30 \mu \mathrm{m}$ thickness were prepared to identify the mineral composition of the waste marble samples. Some of the samples could not be determined by means of polarization microscopy due to the grain size smaller than $2 \mu \mathrm{m}$. Those samples were investigated by differential thermal analysis (DTA) and scanning electron microscope (SEM). The texture of sedimentary marbles was found to be micritic texture; the andesites have porphyritic texture which has phenocrysts in glass. The scanning electron microscope investigation of the texture of the produced cultured marble is shown in Fig. 4. It has clastic texture where the grains are marble surrounded by the resin. The resin is amorphous material, therefore, the light cannot be transmitted through it (appears in dark colour in Fig. 4). Calcite grains are transparent and permit the light transmitting through them (appear in light colour in Fig. 4).

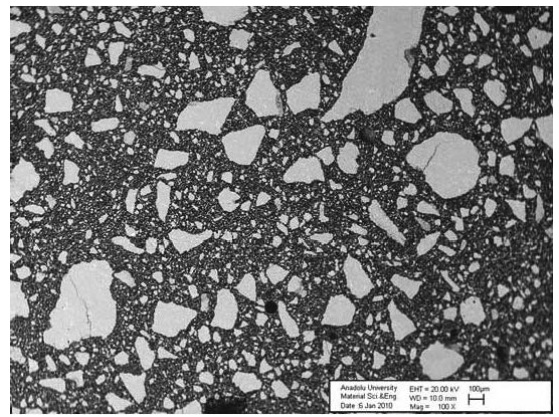

Fig. 4. Clastic texture of artificial marble through secondary electron SEM images of calcite grains (Sample-1, Söbüdağ Limestone, North of Isparta).

4. ábra Mesterséges márvány klasztikus szövete, kalcit szemcsék pásztázó elektronmikroszkópos felvételén (1. sz. minta, Söbüdağ mészkö, ÉszakIsparta).

\subsection{Characterization of the artificial marble}

For the characterization of the calcite and dolomite minerals, SEM and DTA analyses were carried out (Fig. 4 and 5). Sedimentary marbles have micritic texture containing micritic types of calcite and dolomite minerals depending on their composition. They could not be determined by polarization microscopy, therefore, we applied differential thermal analysis (DTA) to study the mineralogical composition, by preparing powder sample. The sample was heated up to $1200^{\circ} \mathrm{C}$ and exothermic and endothermic peaks were noted at certain points. Endothermic peaks between 800 and $900^{\circ} \mathrm{C}$ belong to calcite and dolomite. The obtained results were evaluated by ASTM cards which confirmed the composition of minerals being a mixture of dolomite and calcite.

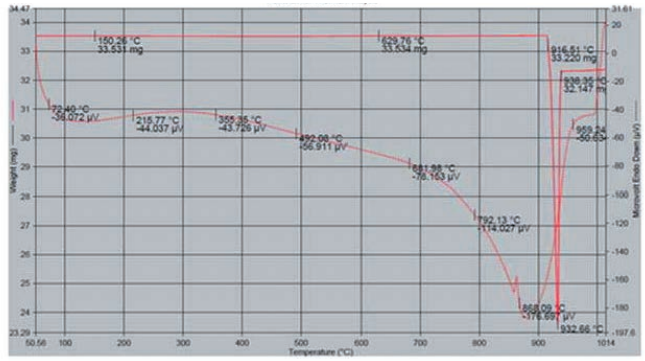

Fig. 5. DTA diagram of carbonate mineral (Söbudağ, North of Isparta). 5. ábra Karbonátos ásvány DTA diagramja (Söbudă̆, Észak-Isparta).

\subsection{Properties of the artificial marbles}

Chemical composition of marble is changing with respect to the type of marbles. Igneous marbles have high $\mathrm{SiO}_{2}$ but sedimentary types of marbles have higher $\mathrm{Ca}-\mathrm{Mg}-\mathrm{CO}_{3}$ (Table 1).

Mineralogy of the minerals used as an additive in artificial marbles controls the quality of the cultured marbles. Therefore, mineralogy of the used additive materials has to be investigated in detail with respect to physical properties. These are especially hardness, grain size and morphology and thermal properties. Raw waste marble samples contain calcite, dolomite, quartz, mica, feldspar, serpentine group minerals and wollastonite. 


\begin{tabular}{|c|c|c|c|c|c|c|c|c|c|c|c|c|}
\hline Sample & & & & & mestor & & & & & Trachy- & Trav & ine \\
\hline Number & GY1 & GY2 & GY3 & GY4 & GY5 & GY6 & GY7 & GY8 & GY9 & GY10 & GY11 & GY12 \\
\hline $\mathrm{SiO}_{2}$ & 0.11 & 0.09 & 0.02 & 0.16 & 0.07 & 0.01 & 0.1 & 0.02 & 0.07 & 57.6 & 0.21 & 0.03 \\
\hline $\mathrm{TiO}_{2}$ & 0 & 0 & 0 & 0 & 0 & 0 & 0 & 0 & 0 & 0.43 & 0.00 & 0.00 \\
\hline $\mathrm{Al}_{2} \mathrm{O}_{3}$ & 0.01 & 0.01 & 0.02 & 0.01 & 0.01 & 0.02 & 0.04 & 0.01 & 0.04 & 17.1 & 0.02 & 0.01 \\
\hline $\mathrm{Fe}_{2} \mathrm{O}_{3}$ & 0.06 & 0.04 & 0.03 & 0.05 & 0.04 & 0.02 & 0.09 & 0.02 & 0.07 & 4.14 & 0.20 & 0.05 \\
\hline MnO & 0.01 & 0.01 & 0.01 & 0.01 & 0.01 & 0.01 & 0.02 & 0.01 & 0.01 & 0.13 & 0.04 & 0.01 \\
\hline MgO & 0.61 & 0.56 & 0.74 & 0.54 & 18.4 & 0.43 & 0.5 & 0.44 & 0.47 & 1.33 & 0.40 & 0.47 \\
\hline $\mathrm{CaO}$ & 53.3 & 54.1 & 53.8 & 54.8 & 33.8 & 54.7 & 53.5 & 54.8 & 54.5 & 4.89 & 53.70 & 54.7 \\
\hline $\mathrm{Na}_{2} \mathrm{O}$ & 0.52 & 0.5 & 0.49 & 0.49 & 0.51 & 0.47 & 0.53 & 0.47 & 0.5 & 5.0 & 0.46 & 0.50 \\
\hline $\mathrm{K}_{2} \mathrm{O}$ & 0.58 & 0.56 & 0.56 & 0.57 & 0.55 & 0.53 & 0.6 & 0.52 & 0.57 & 4.86 & 0.57 & 0.58 \\
\hline $\mathbf{P}_{2} \mathbf{O}_{5}$ & 0.02 & 0.02 & 0.02 & 0.03 & 0.04 & 0.01 & 0.03 & 0.02 & 0.02 & 0.24 & 0.02 & 0.01 \\
\hline Ignition lost & 43.7 & 43.1 & 43.4 & 43.2 & 46.5 & 43.2 & 43.2 & 43.2 & 42.8 & 3.21 & 43.90 & 43.30 \\
\hline Total & 98.9 & 98.9 & 99.2 & 99.8 & 99.8 & 99.5 & 98.6 & 99.6 & 99.2 & 98.9 & 99.60 & 99.70 \\
\hline
\end{tabular}

Table 1. Chemical composition of natural marbles which used for artificial marble production. 1. táblázat A mesterséges márvány készitésére használ márványok kémiai összetétele

Calcite and dolomite belong to carbonate group minerals. Their hardness values are 3 and 4 with respect to Mohs hardness scale, respectively. When artificial marble is produced by using carbonate minerals its compressive strength is lower. As hardness of the minerals increases, its compressive strength increases too. On the other hand, trachy-andesites containing feldspar and quartz which belong to silicate group minerals give higher compressive strength and have higher hardness value between 6 and 7 with respect to Mohs hardness scale.

In artificial marble production, grain size morphology is important if high temperature resistant material is intended to be produced. Wollastonite has fiber grain morphology and is resistant to high temperature [6]. It has a unique property with fibrous morphology and also refractory feature (Fig. 6). The materials containing wollastonite can be used effectively in high temperature conditions. It has also high corrosion resistance. When it is used as an additive material in artificial marbles it may result higher compressive strength, higher durability, refractory feature and corrosion resistance.

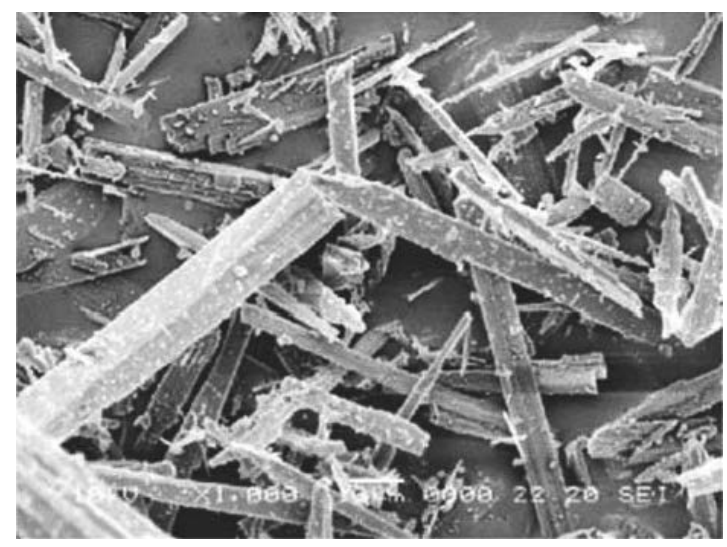

Fig. 6. Fibrous structure of wollastonite (http://www.google.com.tr/imgres) 6. ábra Wollastonit szálas szerkezete (http://www.google.com.tr/imgres)

\begin{tabular}{lccccc}
$\begin{array}{l}\text { Sample } \\
\text { Number }\end{array}$ & $\begin{array}{c}\text { Dry } \\
\text { Weight } \\
(\mathbf{g})\end{array}$ & $\begin{array}{c}\text { After } \\
\mathbf{2 4} \text { Hours }\end{array}$ & $\begin{array}{c}\text { After } \\
\mathbf{4} \text { Hours } \\
(\mathbf{g})\end{array}$ & $\begin{array}{c}\text { 72 Hours } \\
(\mathbf{g})\end{array}$ & $\begin{array}{c}\text { Water } \\
\text { Absorption } \\
(\%)\end{array}$ \\
\hline GY-1 & 250.70 & 250.70 & 250.70 & 250.73 & 0.03 \\
\hline GY-2 & 250.70 & 250.70 & 250.80 & 250.80 & 0.04 \\
\hline GY-3 & 250.57 & 250.57 & 250.60 & 250.60 & 0.03 \\
\hline GY-4 & 249.53 & 249.53 & 249.57 & 249.57 & 0.01 \\
\hline GY-5 & 253.70 & 253.70 & 253.77 & 253.77 & 0.03 \\
\hline GY-6 & 233.67 & 233.67 & 233.83 & 233.83 & 0.07 \\
\hline GY-7 & 246.00 & 246.00 & 246.00 & 246.00 & 0.00 \\
\hline GY-8 & 247.83 & 247.83 & 247.97 & 247.97 & 0.05 \\
\hline GY-9 & 243.43 & 243.43 & 243.43 & 243.43 & 0.00 \\
\hline GY-10 & 245.30 & 245.40 & 245.50 & 245.50 & 0.08 \\
\hline GY-11 & 250.70 & 250.73 & 250.83 & 250.83 & 0.05 \\
\hline GY-12 & 248.93 & 249.00 & 249.10 & 249.10 & 0.07 \\
\hline
\end{tabular}

Table 2. Water absorption of cultured marble samples according to Turkish Standards (TS)

2. táblázat A mesterséges márvány minták vízfelvétele a Török Szabványok (TS) szerint vizsgálva

Grain morphology also controls the quality of artificial marble. Wollastonite and chrysotile have fibrous grain morphology. They contribute to higher strength of the materials similarly to steel reabrs in concrete. Although wollastonite and chrysotile are useful for the best quality of the artifical marble but chrysotile is considered to be carcinogenic so it is not preferred for the production of the cultured marble $[7,8]$.

Weights of wet unit volume (WWUV) of artificial marble cubic samples were evaluated (Table 3). Natural marbles have some porosity which adversely affects the quality of the marble. When natural marbles have porosity of percolated capillaries, water may be absorbed into the material and cause the weathering physically and chemically. Therefore, porosity 
of the marbles should be close to zero (Table 3). The water absorption was found to be low (values vary between $0.00 \%$ and $0.08 \%$ ) for the cultured marble samples tested (Table 3). It means that the products are compact and have negligible amount of porosity. The low porosity can make the material durable against water and air.

\begin{tabular}{llll}
$\begin{array}{l}\text { Sample } \\
\text { Number }\end{array}$ & $\begin{array}{c}\text { WDUV } \\
\left(\mathbf{k g} / \mathbf{m}^{3}\right)\end{array}$ & $\begin{array}{c}\text { WWUV } \\
\left(\mathbf{k g} / \mathbf{m}^{3}\right)\end{array}$ & $\begin{array}{c}\text { Porosity } \\
(\mathbf{n}) \%\end{array}$ \\
\hline GY-1 & 1993.12 & 2004.01 & 5.32 \\
\hline GY-2 & 2015.24 & 2021.15 & 4.12 \\
\hline GY-3 & 2012.89 & 2014.83 & 5.36 \\
\hline GY-4 & 1994.60 & 1997.34 & 6.68 \\
\hline GY-5 & 2044.84 & 2060.28 & 5.08 \\
\hline GY-6 & 1903.50 & 1888.97 & 3.88 \\
\hline GY-7 & 1976.40 & 1972.66 & 3.88 \\
\hline GY-8 & 2010.73 & 2011.22 & 2.40 \\
\hline GY-9 & 1989.50 & 1996.51 & 6.80 \\
\hline GY-10 & 1908.49 & 1908.40 & 10.00 \\
\hline GY-11 & 2026.56 & 2024.98 & 10.00 \\
\hline GY-12 & 1971.53 & 1981.90 & 11.72 \\
\hline
\end{tabular}

Table 3. Weights of dry unit volume (WDUV), weights of wet unit volume (WWUV) and apparent porosity of artificial marble cubic samples

3. táblázat A mesterséges márvány próbakockák mért nedves testsürüsége, száraz testsürüsége és látszólagos porozitása

Table 4 summarizes the compressive strength, the ultrasound pulse velocity and the rebound index values corresponding to the artificial marbles produced.

\begin{tabular}{lccc}
$\begin{array}{l}\text { Sample } \\
\text { Number }\end{array}$ & $\begin{array}{c}\text { Compressive } \\
\text { strength } \\
\text { N/mm }\end{array}$ & $\begin{array}{c}\text { Ultrasound } \\
\text { pulse velocity } \\
\text { Vp (m/s) }\end{array}$ & $\begin{array}{c}\text { Rebound } \\
\text { index }\end{array}$ \\
\hline GY-1 & 106.13 & 3555 & 34 \\
\hline GY-2 & 98.69 & 3509 & 34 \\
\hline GY-3 & 91.21 & 3478 & 34 \\
\hline GY-4 & 72.17 & 3503 & 34 \\
\hline GY-5 & 64.93 & 3406 & 34 \\
\hline GY-6 & 83.51 & 3271 & 34 \\
\hline GY-7 & 82.29 & 3440 & 34 \\
\hline GY-8 & 97.11 & 3461 & 34 \\
\hline GY-9 & 71.86 & 3426 & 34 \\
\hline GY-10 & 61.16 & 3399 & 34 \\
\hline GY-11 & 76.32 & 3516 & 34 \\
\hline GY-12 & 68.88 & 3601 & 34 \\
\hline
\end{tabular}

Table 4. Compressive strength, ultrasound pulse velocity and rebound index of artificial marble cubic samples

4. táblázat A mesterséges márvány próbakockákon mért nyomószilárdság, ultrahang terjedési sebesség és visszapattanási érték

Construction materials should have some physicomechanical values required in building industry. Required values for natural building stones are summarized in Table 5
[9].When we compared cultured marble with natural building stone, our results were found above the required values. Therefore, our produced artificial marbles can be safely used in the building industry as a constructional material.

\begin{tabular}{lccc} 
TS & $\begin{array}{c}\text { Standard } \\
\text { Name }\end{array}$ & $\begin{array}{c}\text { Used } \\
\text { Place }\end{array}$ & $\begin{array}{c}\text { Uniaxial } \\
\text { compressive } \\
\text { strength N/mm }\end{array}$ \\
\hline $\mathbf{1 0 8 3 5}$ & Limestone & Floor covering & $50 \mathrm{~N} / \mathrm{mm}^{2}$ \\
& Wall covering & $30 \mathrm{~N} / \mathrm{mm}^{2}$ \\
\hline $\mathbf{1 1 1 3 5}$ & Trachyte & Floor covering & $100 \mathrm{~N} / \mathrm{mm}^{2}$ \\
\hline $\mathbf{1 0 4 4 9}$ & Wall covering & $60 \mathrm{~N} / \mathrm{mm}^{2}$ \\
\hline $\mathbf{1 1 1 4 3}$ & Marble (calcium & Wall covering & $50 \mathrm{~N} / \mathrm{mm}^{2}$ \\
& carbonate) & Floor covering & $50 \mathrm{~N} / \mathrm{mm}^{2}$ \\
& Travertine & Floor covering & $48 \mathrm{~N} / \mathrm{mm}^{2}$ \\
& & Wall covering & $30 \mathrm{~N} / \mathrm{mm}^{2}$ \\
\hline
\end{tabular}

Table 5. Minimum values required by the uniaxial compressive strength (TS EN 1926) 5. táblázat Egytengelyü nyomószilárdság elöírt legkisebb értékei (TS EN 1926)

\section{Conclusions}

Large quantities of marble blocks are produced from many new marble quarries which were opened around Isparta (Turkey) and its surrounding region. Block efficiency of the quarries is low which results in a lot of waste materials that can be used in cultured marble production. The cultured marble is an attractive, healthy and homogenous building material. It has a wide application in the building sector. Artificial marble which is composed of mineral waste materials and polyester resins has high compressive strength, durable to various chemical and high temperature environmental conditions. Based on physico-mechanical properties, cultured marbles are accepted by the Turkish Standards (TS). Physico-mechanical properties of cultured marble depend on the physical properties of the filler minerals. The following analyses; wet unit volume analysis, dry unit volume analysis, compressive strength of the materials, capillary water absorption analysis, ultrasound pulse velocity analysis and the marble wastes bulk chemical analyses were carried out and the results were evaluated and discussed with respect to the physico-mechanical properties.

\begin{tabular}{lccc} 
Tensile Strength & $\mathbf{4 5}$ & MPa & ISO 527 \\
Breaking Elongation & 1.3 & $\%$ & ISO 527 \\
\hline Tensile Modulus & 3800 & $\mathrm{MPa}$ & ISO 527 \\
\hline Bending Strength & 70 & $\mathrm{MPa}$ & ISO 178 \\
\hline Bending Modulus & 3900 & $\mathrm{MPa}$ & ISO 178 \\
\hline HDT & 95 & ${ }^{\circ} \mathrm{C}$ & ISO 75A \\
\hline
\end{tabular}

\begin{tabular}{llll}
\hline Hardness & 45 & Barcol & $934-1$ \\
\hline
\end{tabular}

Table 6. Various physico-mechanical values of resins

6. táblázat Mügyanták különféle fizikai/mechanikai jellemzői 
Construction materials should have important physicomechanical values required in building industry. When we compared our artificial marbles with natural building stones, our results all met the requirements. Therefore, our artificial marbles can be safely used in the building industry as a construction material. The artificial marbles are resistant to acids, alkalis and they are cheap and durable so there is a huge potential in them to be used in harsh environments. Artificial marble has anti-bacterial property so it has been widely used in baths, hospitals, hotels, restaurants. Artificial marble production has positive effect on environmental concerns by elimination of marble wastes as well.

\section{Acknowledgments}

Authors are thankful to Prof. Dr. Lütfullah Gündüz in Pumice Applied Research Center Manager of Suleyman Demirel University for the analyses of all of the physico-mechanical properties of the artificial marbles.

\section{References}

[1] Bilgin, A. - Özkahraman, T.: Marble potential of Isparta and some related problems. International Symposium on Engineering and Architectural Sciences, Balkan Caucasus and Turkic Republics. I, 22-24 October, Isparta, Turkey, pp. 231-237. 2009

[2] Bilgin, N. - Yeprem, H. A. - Arslan, S. - Bilgin, A. - Günay, E. - Marşoğlu, M.: Use of Waste Marble Powder in Brick Industry. Construction and Building Materials, Issue 4, Vol. 29, pp. 449-457. 2012

[3] Hussin, K. - Baharin, S. - Ghazali, C.. M. R. - Idris, M. S. - Salleh, M. N. I. K. N.: The Development Of Artificial Marble From Dolomite (Batu Reput) In Perlis. KUKUM Engineering Research Seminar, 2006

[4] Aruniit, A. - Kers, J. - Tall. K.: Influence of filler proportion on mechanical and physical properties of particulate composite. Agronomy Research Biosystem Engineering Special Issue 1, pp. 23-29. 2011

[5] Lee, M. Y.: Anti-bacterial self-cleansing stone slab and its manufacturing method. TW Patent 189048. 2004

[6] Berry, L. G. - Mason, B. - Dietrich, R. V.: Mineralogy. Freeman and Company, San Francisco, p. 459. 1983

[7] Chen, T. W. - Ding, Y. C - Chiu, J. P.: A study of synthetic forsterite refractory materials using waste serpentine cutting. Minerals Engineering, 15, pp. 271-275. 2002

\section{FOLYÓIRATSZEMLE}

\section{A. Hellebois, A. Launoy, C. Pierre, M. De Lanève, B. Espion: 100-year-old Hennebique concrete, from composition to performance}

Construction and Building Materials (Elsevier) ISSN 0950-0618, Volume 44 (2013) pp. 149-160.

A belga szerzők angol nyelvű cikke egy 1904-ben épült, 2010-ben elbontott vasbeton vasúti híd beton anyagának a vizsgálatait mutatja be. A híd (Viaduc Colo-Hugues) Belgiumban, Braine-l'Alleud városában épült Hennebique eredeti szabadalma alapján. A híd eredetileg egy 13-nyílású, 73 m hosszú, 3,80 m széles szerkezet volt, amelyet az 1960-as évektől nem használtak, és a vizsgálatok időpontjában már csak öt nyílása volt meg. A 106 éves szerkezet korához képest jó állapotban volt a vizsgálatok időpontjában annak ellenére, hogy a Hennebique-féle kivitelezési technológia (pl. távtartókat nem használtak a betonacélok elhelyezésekor) következtében már a kivitelezés során kialakultak káros elváltozások (kis betonfedés a pontatlan betonacél elhelyezés miatt; fészkes, rosszul bedolgozott beton stb.). Elvégezték a nyomószilárdság, hasító-húzószilárdság, rugalmassági modulus, testsűrűség, vízfelvétel, karbonátosodási mélység, klorid-ion tartalom, cement tartalom
[8] Lee, M-Y. - Ko, C-H. - Chang, F-C. - Lo, S-L. - Lin, J-D. - Shan, M-Y. - Lee, J-C.: Artificial stone slab production using waste glass, stone fragments and vacuum vibratory compaction. Elsevier, Cement \& Concrete Composites, 30, pp. 583-587. 2008

[9] Yücetürk, G.: Yapay mermerde kullanilan kuvars ve kalsit minerallerinin fiziko mekanik özellikleri. Constructional Technology, V.2, 3, pp. 72-80. 2010

Ref.:

A. Bilgin - G. Yuceturk - S. Arslan - N. Bilgin - S. Polat: The effects of mineralogical and petrographical features of the Lake District rocks (Isparta, Turkey) on the quality of artificial marbles. Építőanyag, 65. évf. 1. szám (2013), 21-25. p. http://dx.doi.org/10.14382/epitoanyag-jsbcm.2013.5

A Lake District kőzetek (Isparta, Törökország) ásványtani és kőzettani jellegzetességeinek hatása mesterséges márványok minőségére

Törökországban, Isparta város környezetében számos márványbánya nyílt az elmúlt évtizedekben. A helyenként számottevố karsztosodás miatt a kôzettömbök kitermelésének hatékonysága nem optimális, és nagy mennyiségú hulladék márvány töret keletkezik. A hulladék anyag depóniák jelentôs vizuális szennyezést eredményeznek. A hulladék márvány alkalmas mesterséges márvány készítésére, poliészter gyantával kombinálva. A mesterséges márvány nagy tartósságú építōanyag, ellenáll agressziv kémiai hatásoknak és esetenként magas hômérsékletnek is, ezért a Török Szabványok (TS) elfogadják a mesterséges márvány építôanyagként történố alkalmazását. A mesterséges márvány fizikai/mechanikai jellemzổi elsốsorban a márvány zúzalék és por jellemzôitốl függnek, így azok kémiai elemzése kiemelt jelentôségú. A cikk az Isparta közelében elhelyezkedố egyes márványbányákból származó hulladék márvány felhasználásával készített mesterséges márvány minták vizsgálatait mutatja be. Elemzi a vízfelvételi, tömegeloszlási, porozitási, nyomószilárdsági, ultrahang terjedési és felületi keménységi vizsgálatok eredményeit, illetve bemutatja a vizsgálatokhoz kapcsolódó termogravimetriai és pásztázó elektronmikroszkópos vizsgálatok egyes eredményeit. A bemutatott eredmények alátámasztják a megvizsgált mesterséges márványok építôiipari alkalmazhatóságát.

Kulcsszavak: mesterséges márvány, poliészter gyanta, márványbánya, nyomószilárdság vizsgálatát. Az adalékanyag feltárását követően annak szemeloszlási és petrográfiai jellemzőit is meghatározták. Az eredmények szerint a szerkezeti elemek cement tartalma $\left(\mathrm{c}, \mathrm{kg} / \mathrm{m}^{3}\right)$ és nyomószilárdsága $\left(\mathrm{f}_{\mathrm{cm}}, \mathrm{MPa}\right)$ változatos volt: pillérek $c=131-144 \mathrm{~kg} / \mathrm{m}^{3}$ és $f_{c m}=19,7 \mathrm{MPa}$; gerendák $c=247-273$ $\mathrm{kg} / \mathrm{m}^{3}$ és $\mathrm{f}_{\mathrm{cm}}=34,6 \mathrm{MPa}$; lemezek $\mathrm{c}=291-308 \mathrm{~kg} / \mathrm{m}^{3}$ és $\mathrm{f}_{\mathrm{cm}}=54,2 \mathrm{MPa}$. A petrográfiai vizsgálatok szerint az adalékanyag egy, a közelben megtalálható, nagy szilárdságú, de erózióra hajlamos, andeztit-dácit típusú, porfiros kőzetanyagból készülhetett. A szemeloszlási vizsgálatok szerint az adalékanyag 0,5 mm/2,0 mm frakciója csaknem teljesen hiányzott a keverékből, ezzel szemben a $0,25 \mathrm{~mm} / 0,5 \mathrm{~mm}$ frakció a napjainkban megszokottnál nagyobb mennyiségben került a betonba. A karbonátosodás átlagos mélysége 18,6 mm volt a pilléreknél, 18,7 mm volt a gerendáknál és $8,3 \mathrm{~mm}$ volt a lemezeknél. A betonacélokat a karbonátosodás mélysége csak kevés helyen érte el. A szerkezeti beton klorid-ion tartalma a kritikus klorid-ion tartaIom (0,4 m\%/cement) egy tizedét sem érte el, amely a korabeli kalcium-klorid adalékszerből származott. A vizsgálatok bizonyították, hogy a XX. század elején elérhető anyagokkal és technológiákkal is lehetett nagy tartósságú betonszerkezeteket építeni abban az esetben, ha az anyagválasztás, a tervezés és a kivitelezés megfelelő és gondosan ellenőrzött volt. 